\title{
Impact of psychological distress due to COVID-19 pandemic on spouse interpersonal relationships
}

\author{
Urmi Chakraborty ${ }^{1}$, Manoj Kumar Pandey ${ }^{2}$, Deepti Mishra ${ }^{3}$, Neeraj Kumar Mishra ${ }^{4}$, \\ Aditi Bapte ${ }^{5}$ \\ ${ }^{1}$ Clinical Psychologist, Department of Clinical Psychology, Dr. RML Hospital, New Delhi \\ ${ }^{2}$ Assistant Professor, Department of Applied Psychology, Veer Bahadur Singh Purvanchal University, \\ Jaunpur \\ ${ }^{3} \mathrm{PhD}$ Scholar, Department of Applied Psychology, Veer Bahadur Singh Purvanchal University, Jaunpur \\ ${ }^{4} \mathrm{PhD}$ Scholar, Department of Applied Psychology, Veer Bahadur Singh Purvanchal University, Jaunpur \\ ${ }^{5}$ Research Assistant, Indian Council of Social Science Research, New Delhi
}

Corresponding author: Urmi Chakraborty

Email - urmipsy83@gmail.com

\begin{abstract}
Background: The novel virus, COVID-19, has proven to be a stressor on many levels due to factors like health, economic disruptions, lockdown, and stay-at-home orders. However, one of the significant stressors has been on relationships, primarily the intimate ones, like between spouses. To investigate the correlation between psychological distress and quality of spouse interpersonal relationships.

Methodology: The mixed research design (i.e., qualitative and quantitative methods) was employed on 119 participants between 22-62 years of age, followed by a semi-structural interview of 12 participants, all through virtual snowball mode due to the COVID-19 scenario. Socio-demographic profile, psychological distress scale, and the quality of spouse interpersonal relationships scale and a semi-structural interview schedule were used for data collection.

Results: The present study shows that psychological distress is negatively correlated with certain aspects like conflict, criticism, resentment, pressure, dominance, relative power, and exclusion of the quality of spouse interpersonal relationships. On the other hand, a positive correlation was observed with affection, emotional support, reliable alliance, satisfaction, companionship, and approval aspects of the quality of spouse interpersonal relationships. Qualitative results shows that argument with each other, disagreement, point out faults, pressurization for intimation, and violence with partner are some of the most prominent negative effects in their present life while developed understanding to each other, sense of trust, feel good, received love and affection, care for each other, emotional support, help in other household errands, and take care of children and parents are some of the positive aspects seen instead of the psychological distress perceived during this pandemic.

Conclusions: COVID-19 has had considerable effects on spousal interpersonal relationships and needs further study.
\end{abstract}

Keywords: COVID-19, Psychological distress, Spouse interpersonal relationships, Stressor.

(Paper received $-16^{\text {th }}$ October 2020, Peer review completed $-8^{\text {th }}$ December 2020)

(Accepted $-15^{\text {th }}$ December 2020)

\section{INTRODUCTION}

COVID-19 pandemic has drastically affected not just the physical but also the overall mental health of humans. In the past, pandemics like SARS have shown extreme psychological difficulties, like stress, anxiety, etc. and the effects are carried over post-outbreak too. The fear of family members being infected by the virus permeates all levels and is an excellent cause of perceived stress. Xiang et al. highlighted that 
the epidemic had caused psychological distress, like nervousness, fear of infection, anxiety, sleep problems among the general population [1]. In the past, there were research highlighting the impact of various epidemics, natural disasters, or long-term unemployment on various psychological aspects [2-4].

While the virus drastically affects people of older age bracket and co-morbidities, studies have shown an impact on the younger population, who majorly remain asymptomatic carriers. Considering these factors and the subsequent lockdown, the perception of social life has dramatically changed. Brooks et al. [5] cited that the measures undertaken to limit the outbreak like quarantine and self-isolation, can also lead to lasting distress. Germani, A., et al. mentioned in their research that adults showed a high-level of concern for their relatives compared to themselves [6]. This highly shifts the focus on how the interpersonal skills are perceived during COVID-19 times, as the focus has truly shifted from individualism to collectivism.

The pandemic has reported a significant number of cases of drug and alcohol consumption, further leading to Intimate Partner Violence (IPV) [7], which added on the self-blame for the violence experienced by the victim [8]. Kaukinen cited that the factors responsible for IPV during this pandemic were economic slowdown, male unemployment, and increased stressors at home [9]. It is not just violence but also financial instability, which also caused an increase in the rate of divorce and marital conflict. Due to the isolation from social life, the pressure was more on the partners' interpersonal equation. As the pressures increase, the feeling of togetherness and emotional connection decreases [10]. This further adds to hostility and dominance, among other things.

The pandemic has also brought about social disruption, in terms of caregiving burden, confinement related stress, which would not end soon. Interpersonal relationships are guided by the external environment, like the COVID-19, in this case, as well as the proximal factors like the relationship with family members, teachers, etc. The contextual risk altered the interpersonal relationship inside the family [11].

The effect is also equally evident on the caregivers and their well-being, even if unemployment is not an immediate threat. The stressors that affect one family member can extend to the other members of the family. The interpersonal relationships have both brought a positive impact, giving more family time, and for some, the stay-at-home experience has been unsafe. The family is considered important than its parts and builds on belief systems, communication, and organization.

One of the significant stressors has been on intimate relationships, primarily due to external stressors and existing vulnerabilities. The current pandemic situation has increased the dyadic processes that undermine the couple's relationships regarding the situation and individual vulnerabilities, like depression, attachment insecurity, etc. [12]. Studying the impact of spouse interpersonal relationships seems important as past researches have highlighted how disruptions in economic, mental health are closely related with spouse relationship functioning [13]; this less satisfaction further leads to arguments, criticizing, blaming [14 - 15]. The stressful conditions have a significant effect soon, even on how newlyweds showed low problem-solving effectiveness. Hence, the current scenario calls for more profound action to assess the spouse's interpersonal relationships during the COVID-19 times.

Based on the review of literature, following relationships are being proposed:

- There will be a mixed impact between psychological distress due to the pandemic and spouse interpersonal relationships among couples.

- There will be an age-based differences in assessing psychological distress, as well the spouse interpersonal relationships.

- There will be a gender-based differences in assessing psychological distress, as well the spouse interpersonal relationships.

- There will be a nature of based differences in assessing psychological distress, as well the spouse interpersonal relationships.

\section{METHODOLOGY}

\section{Research Design}

Mixed results design was used for this study, i.e., quantitative research design (correlation between psychological distress and spouse interpersonal relationships) followed by a semi-structured interview to 
explore the different affects due to the pandemic on spouse interpersonal relationships and exploring the different psycho-social and environmental strategies for improving or manage the negative impact of the pandemic on their relationships.

\section{Sample}

A total of 119 participants aged between 22 to 62 years took part in this study. Further, the age of the demography was categorized into three groups, viz. 22-30, 31-40 and ages above 40. An online questionnaire was developed using google forms, with an added consent form. The online link was then shared through emails, WhatsApp, and other social media platforms. A semi-structured interview was conducted on 12 participants ( 6 Male \& 6 Female), the age range was 24 to 45 years, and all the participants belonged to the city.

\section{Inclusion Criteria}

- All participants were married.

- Participants who consented to be a part of the study.

\section{Exclusion Criterion}

Person who are not well versed with usage of online platform for data entry and submission.

\section{Tools Used}

Socio-Demographic Profile: Semi-Structured Performa was designed especially for the study. Information about the socio-demographic variables like age, gender, religion, social category, habitation, type of family, and work from home status.

Psychological Distress Scale: Psychological distress is measure in terms of the amount of distress perceived by married people during this corona pandemic. Bilingual (Hindi and English) adaptation of the psychological distress scale developed initially by Kessler et al. was used to assess the amount of psychological distress [16]. The scale consists of 11 items about emotional states, each with a five-point response scale. The lower scores of the scale indicate lesser psychological while higher scores indicate a higher amount of psychological distress due to the pandemic. The Cronbach's alpha coefficient of this adapted scale is 0.891 on 11 items.

The Spouse Interpersonal Relationship: The spouse interpersonal relationships were operationalized in terms of the quality of interpersonal relationships among married couples in this pandemic situation. The measure covers both negative and positive aspects of their interpersonal relationships. Positive aspects included item such as affection, emotional support, reliable alliance, satisfaction, the reassurance of worth, companionship, and approval. In contrast, negative aspects include moment of conflict, face criticism, antagonism/resentment, pressure, dominance, relative power, and exclusion from their day to day activities. This subscale is one of the parts of the quality of interpersonal relationship scale developed by Pandey (2020) [17] to assess the quality of interpersonal relationships during a crisis situation. The scale consists of 14 (7 positive and 7 negative) items about emotional states, each with a five-point response scale. The lower scores of the scale indicate better interpersonal relationships, while higher scores indicate worsen interpersonal relationships among married couples. The Cronbach's alpha coefficient of this adapted scale is 0.846 on 14 items.

Managing or Improving the Spouse Interpersonal Relationship: A semi-Structured interview was conducted to explore the factors that can improve the negative impact of corona pandemic on spouse interpersonal relationships. Open-ended questions were asked to the participants such as:

In this corona pandemic and lockdown

- How do you feel? How does this crisis has affected the relationship with your spouse? and

- What are the possible ways that improve your relationship with your spouse, and how?

\section{Procedure}


During this present COVID-19 scenario, when the Indian government had put restrictions on the public's general movements by imposing lockdowns, and face-to-face interactions were discouraged, the study's data were collected through online mode. A virtual snowball sampling technique was used for this study. A semistructured survey using Google form along with a participant consent form were sent to the researchers' contact. The survey was electronically sent through emails or various social media platforms in India. In order to access a larger population, the survey was bilingual (Hindi and English) in nature.

Moreover, the contacts who received the survey link were encouraged to disseminate the survey among other people freely. Once the respondent agreed to participation, they were asked to fill their demographic and COVID-19 related information. Personal identifiers were excluded from the survey to ensure the anonymity of the participant. The approximate time to complete the survey was 20 minutes. Dedicated contact details (email and phone number) were provided in the survey form to respond to any queries or clarifications from the participants. After that, several mandatory questions were presented consecutively. The entire data were collected from April 2020 to July 2020.

\section{STATISTICAL ANALYSIS}

Statistical Package for Social Sciences (SPSS) version 25.0 was used to carry out the statistical analysis. Descriptive statistics were carried out to describe general characteristics of the study sample. One-way Analysis of Variance (ANOVA) was conducted to see the mean difference on demographic variables and outcome variables. Further, for the analysis and interpretation of semi-structures interview data, content analysis was done to find out the categories and major themes.

\section{RESULTS}

Table- 1. Socio-Demographic and Personal Details of the Sample

\begin{tabular}{|c|c|c|c|}
\hline \multirow{2}{*}{ Demographic Variables } & \multicolumn{3}{|c|}{ Sample Size (N = 119) } \\
\cline { 2 - 4 } & Category & n & Percentage \\
\hline \multirow{3}{*}{ Age } & $22-30$ & 20 & 16.8 \\
\cline { 2 - 4 } & $31-40$ & 59 & 49.6 \\
\cline { 2 - 4 } & $>40$ & 40 & 33.6 \\
\hline \multirow{3}{*}{ Gender } & Male & 60 & 50.4 \\
\cline { 2 - 4 } & Female & 59 & 49.6 \\
\hline \multirow{3}{*}{ Religion } & Hinduism & 98 & 82.4 \\
\cline { 2 - 4 } & Islam & 11 & 9.2 \\
\cline { 2 - 4 } & Others & 9 & 8.4 \\
\hline \multirow{3}{*}{ Social Category } & General & 85 & 71.4 \\
\cline { 2 - 4 } & OBC & 24 & 20.2 \\
\cline { 2 - 4 } & SC/ST & 10 & 8.4 \\
\hline \multirow{3}{*}{ Habitation } & Village & 21 & 17.6 \\
\cline { 2 - 4 } & City & 88 & 73.9 \\
\cline { 2 - 4 } & Town & 10 & 8.4 \\
\hline Nature of Family & Nuclear & 66 & 55.5 \\
\cline { 2 - 4 } & Joint & 53 & 44.5 \\
\hline
\end{tabular}

Table 1 illustrates that the maximum percentage (49.6\%) of the participants were in the age group of 31-40 years. Among them, 50.4\% were male and majority (82.4\%) were Hindus. Most of the participants, i.e. $71.4 \%$ participants belonged to the general category. Among the survey takers, $73.9 \%$ participants lived in city. About $55.5 \%$ participants lived in a nuclear family while $44.5 \%$ lived in a joint family.

Table 2: Psychological Distress and Quality of Spouse Interpersonal Relationship- QSIR 


\section{Psychological Distress and Quality of Spouse Interpersonal Relationship- QSIR (Negative)}

\begin{tabular}{|c|c|c|c|c|c|c|c|c|}
\hline $\begin{array}{c}\text { Dependent } \\
\text { Variable }\end{array}$ & $\begin{array}{c}\text { QSIR } \\
\text { Negative }\end{array}$ & \multicolumn{6}{|c|}{ Aspects of Quality of Spouse Interpersonal Relationship- QSIR (Negative) } \\
\cline { 3 - 8 } & $\begin{array}{c}\text { Moment } \\
\text { of } \\
\text { Conflict }\end{array}$ & $\begin{array}{c}\text { Face } \\
\text { Criticism }\end{array}$ & $\begin{array}{c}\text { Antagonism/ } \\
\text { Resentment }\end{array}$ & Pressure & Dominance & $\begin{array}{c}\text { Relative } \\
\text { Power }\end{array}$ & Exclusion \\
\hline $\begin{array}{c}\text { Psychologi } \\
\text { cal } \\
\text { Distress }\end{array}$ & $-.522^{* *}$ & $-.465^{* *}$ & $-.508^{* *}$ & $-.502^{* *}$ & $-.441^{* *}$ & $-.384^{* *}$ & $-.313^{* *}$ & $-.297^{* *}$ \\
\hline & \multicolumn{7}{|c|}{${ }^{* *}$ Correlation is significant at the 0.01 level (2-tailed). } \\
\hline
\end{tabular}

Psychological Distress and Quality of Spouse Interpersonal Relationship- QSIR (Positive)

\begin{tabular}{|c|c|c|c|c|c|c|c|c|}
\hline $\begin{array}{c}\text { Dependent } \\
\text { Variable }\end{array}$ & $\begin{array}{c}\text { QSIR } \\
\text { Positive }\end{array}$ & \multicolumn{6}{|c|}{ Aspects of Quality of Spouse Interpersonal Relationship- QSIR (Positive) } \\
\cline { 3 - 9 } & & Affection & $\begin{array}{c}\text { Emotional } \\
\text { Support }\end{array}$ & $\begin{array}{c}\text { Reliable } \\
\text { Alliance. }\end{array}$ & Satisfaction & $\begin{array}{c}\text { Reassurance } \\
\text { of Worth }\end{array}$ & Companionship & $\begin{array}{c}\text { Appr } \\
\text { oval }\end{array}$ \\
\hline $\begin{array}{c}\text { Psychologic } \\
\text { al Distress }\end{array}$ & $.280^{* *}$ & $.125^{\text {ns }}$ & .089 & $.125^{\text {ns }}$ & $.248^{* *}$ & $.337^{* *}$ & $.201^{*}$ & $.276^{* *}$ \\
\hline
\end{tabular}

Based on Table 2.a., it could be noted that psychological distress is negatively correlated with certain aspects like conflict, criticism, resentment, pressure dominance, relative power, and exclusion of the Quality Spouse Interpersonal Relationships- QSIR. Whereas Table 2.b. highlights that the psychological distress is positively correlated with affection, emotional support, reliable alliance, satisfaction, companionship and approval aspects of the Quality Spouse Interpersonal Relationships-QSIR. The obtained results support the hypothesis.

Conflict depicts how often there is disagreement, fight or misunderstanding with one another. Current researches highlight that the conditions of lockdown have created an atmosphere of confinement and isolation, increasing the risk of interpersonal conflict in families [18]. Similarly, criticism, resentment, pressure (pushing to do things the other person does not want to do), dominance (making decision for both the individuals), power, exclusion (not including the other person in activities, ignoring or not giving attention) eventually hampers the interpersonal relationship. Studies have shown that women are at higher risk of facing domestic violence [19]. Also, another study has revealed that the number of divorce appointments has risen in number since March, 2020 [20].

Psychological distress is also found responsible for creating positive affection, emotional support (turning for support for personal problems, help or advice), reliable alliance, satisfaction (happy with the relationship), reassurance of worth, companionship (spending fun time with the person, going places and doing things together) and approval (praise, how often the other person feels proud of the other person) in the Quality of Spouse Interpersonal Relationships-QSIR.

Previous studies also show how Psychological Distress is related to interpersonal relationships. There was a significant correlation between psychological distress and three factors of interpersonal relationships in special education teachers and there was a negative impact on the fourth factor of interpersonal relationships [21]. However, a study conducted by Kenny, R., Dooley, B., \& Fitzgerald, A. [22] on 260 adolescents in Dublin found that high levels of interpersonal relation satisfaction showed low emotional distress. Thus, reassuring the association of both the variables of the study. Luetke, et al., had shown how the disruption in routine due to the global pandemic can lead to overall increase in stress and conflict between partners and how the two variables are negatively correlated [23].

\section{Affects Of Pandemic And Lockdown On The Spouse Interpersonal Relationship}

Table 3, depicts that during the pandemic and lockdown, the spouses developed maximum understanding of each other, followed by trust and feeling good in each other's company, where developing understanding stood at $83.34 \%$. Novel researches in Argentina has also shown that the Argentinian male spouse equally 
shared the unpaid work like housework, childcare, educational support during the lockdown [24], also citing (re) connection/cohesion between couples in the family in Spain (Günther-Bel, et al., 2020) [25].

Whereas, the pandemic and the stay-at-home have shown an increase in arguments (58.34\%), pointing out faults and pressuring for intimation (58.34\%). As pointed out by Günther-Bel, et al., [25] there is also a deterioration theme like conflict and couple/family distance observed during the pandemic.

\section{Managing Or Improving the Negative Affects Of Pandemic And Lockdown On The Spouse Interpersonal Relationship}

Table 4, above enlists the possible coping strategies for the spouses to overcome the stress, disagreement, resolve conflict, self-introspection, inter-communication improvement, developing a sense of obligation, recognizing stressors, and seeking professional help. The study showed that communication and respect for each other's differences made a significant difference in conflict resolution (66.67\%), followed by humor and warmth, and emotional support ( $58.34 \%$ each). Similarly, dialogue for rudeness and frustration lead to selfintrospection, active listening, taking care of children, and the elderly in the family were some coping strategies which helped during the lockdown for the spouse interpersonal relationship. Brooks, et al., cited the fear, stress associated with quarantine [5] and Morales-Vives, et al., cited that people with high resilience and life satisfaction coped better to lockdown with positive attitude and behaviour [26].

Table-3. Showing the major themes in terms of different positive and negative affects perceived by participants during this pandemic and lockdown associated with the spouse interpersonal relationship

\begin{tabular}{|c|c|c|c|c|}
\hline $\begin{array}{l}\text { Major } \\
\text { Themes }\end{array}$ & Categories & Codes (With Interpretation) & f & $\%$ \\
\hline \multirow{12}{*}{$\begin{array}{l}\text { Positive } \\
\text { Affects }\end{array}$} & \multirow{5}{*}{ Interpersonal Bonding } & $\begin{array}{l}\text { - Developed understanding to each } \\
\text { other }\end{array}$ & 10 & 83.34 \\
\hline & & - Developed sense of trust & 7 & 58.34 \\
\hline & & - Affection and love & 6 & 50.00 \\
\hline & & - Companionship & 4 & 33.34 \\
\hline & & - Feel good & 7 & 58.34 \\
\hline & \multirow{4}{*}{ Support System } & - Emotional support & 6 & 50.00 \\
\hline & & - Care for each other & 8 & 66.67 \\
\hline & & - Sharing the economic crisis & 3 & 25.00 \\
\hline & & - Appraisal or praise & 5 & 41.67 \\
\hline & \multirow{3}{*}{ Help in House-hold chores } & - Help in kitchen & 4 & 33.34 \\
\hline & & - Help in other household errands & 5 & 41.67 \\
\hline & & - Taking care of children and parents & 4 & 33.34 \\
\hline \multirow{10}{*}{$\begin{array}{l}\text { Negative } \\
\text { Affects }\end{array}$} & \multirow{4}{*}{ Moment of Conflict } & - Quarreling & 3 & 25.00 \\
\hline & & - Disagreement & 5 & 41.67 \\
\hline & & - Argument with each other & 7 & 58.34 \\
\hline & & - Personal hassle & 4 & 33.67 \\
\hline & \multirow{3}{*}{ Criticizing each other } & - Point out faults & 4 & 33.67 \\
\hline & & - Try to put down & 3 & 25.00 \\
\hline & & - Sometimes mean or harsh to me & 2 & 16.67 \\
\hline & \multirow{3}{*}{ Pressurization for Intimation } & - Try to dominate & 4 & 33.67 \\
\hline & & - Pressure & 7 & 58.34 \\
\hline & & - Violence & 4 & 33.67 \\
\hline
\end{tabular}

Table-4. Showing the major themes in terms of different psycho-social \& environmental strategies suggested by participants during this pandemic and lockdown to improve the negative outcomes of spouse interpersonal relationship.

\begin{tabular}{|c|c|c|c|c|c|}
\hline Major Issues & $\begin{array}{c}\text { Major } \\
\text { Themes }\end{array}$ & Categories & Codes (With Interpretation) & $\mathbf{f}$ & $\%$ \\
\hline
\end{tabular}




\begin{tabular}{|c|c|c|c|c|c|}
\hline \multirow{7}{*}{$\begin{array}{l}\text { Moment of } \\
\text { Conflict } \\
\text { - Quarreling } \\
\text { - Disagreement } \\
\text { - Argument with } \\
\text { each other } \\
\text { - Personal hassle }\end{array}$} & \multirow{16}{*}{ 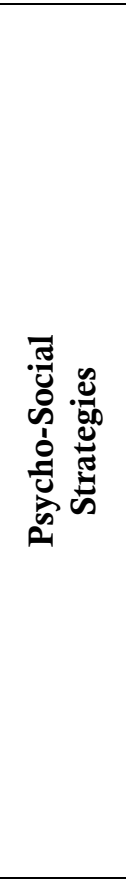 } & \multirow{7}{*}{$\begin{array}{l}\text { Conflict } \\
\text { Resolution }\end{array}$} & - Reconciliation and patience & 4 & 33.34 \\
\hline & & & - Humor \& warmth & 7 & 58.34 \\
\hline & & & - Positivity \& Efforts to resolve & 6 & 50.00 \\
\hline & & & $\begin{array}{l}\text { - Communication and respect each } \\
\text { other's differences }\end{array}$ & 8 & 66.67 \\
\hline & & & $\begin{array}{l}\text { - Compassionate towards each } \\
\text { other frustration, losses, etc }\end{array}$ & 3 & 25.00 \\
\hline & & & - Emotional Support & 7 & 58.34 \\
\hline & & & $\begin{array}{l}\text { - Respect of each-other Personal } \\
\text { Space }\end{array}$ & 5 & 41.67 \\
\hline \multirow{7}{*}{$\begin{array}{l}\text { Criticizing each } \\
\text { other } \\
\text { - Point out faults } \\
\text { - Try to put } \\
\text { down } \\
\text { - Sometimes } \\
\text { mean or harsh } \\
\text { to each other }\end{array}$} & & \multirow{3}{*}{$\begin{array}{c}\text { Self - } \\
\text { Introspection }\end{array}$} & - Suggest self-realization & 5 & 41.67 \\
\hline & & & - Assertion of the needs and opinion & 6 & 50.00 \\
\hline & & & $\begin{array}{l}\text { - Dialogue about the reason of } \\
\text { rudeness and what is frustrating }\end{array}$ & 8 & 66.67 \\
\hline & & \multirow{3}{*}{$\begin{array}{c}\text { Inter- } \\
\text { Communication } \\
\text { Improvement }\end{array}$} & - Blame Game is not the solution & 7 & 58.34 \\
\hline & & & - Active Listening & 9 & 75.00 \\
\hline & & & - Make time for Fun & 5 & 41.67 \\
\hline & & \multirow{3}{*}{$\begin{array}{l}\text { Developed a } \\
\text { Sense of } \\
\text { Obligation }\end{array}$} & - Taking care of Children and & 8 & 66.67 \\
\hline \multirow{7}{*}{$\begin{array}{l}\text { Pressurization } \\
\text { for Intimation } \\
\text { - Try to dominate } \\
\text { - Pressure } \\
\text { - Violence }\end{array}$} & & & Parents are our Responsibility & & \\
\hline & & & - Sharing the Economic Burden & 4 & 33.34 \\
\hline & \multirow{5}{*}{ 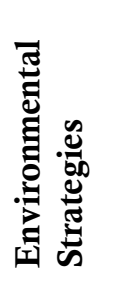 } & \multirow{4}{*}{$\begin{array}{l}\text { Recognizing } \\
\text { Stressors \& } \\
\text { Preparing for } \\
\text { Plan of Action }\end{array}$} & - Helplessness but not Hopeless & 8 & 66.67 \\
\hline & & & - Economic Crisis & 5 & 41.67 \\
\hline & & & - Children's Education & 6 & 50.00 \\
\hline & & & - Social Relationship & 4 & 33.34 \\
\hline & & $\begin{array}{l}\text { Professional } \\
\text { Help }\end{array}$ & $\begin{array}{l}\text { Try to involve a third party or } \\
\text { therapist to help resolve matters }\end{array}$ & 5 & 41.67 \\
\hline
\end{tabular}

\section{CONCLUSION}

The study undertaken shows the impact of psychological distress on the spouse's interpersonal relationships during the COVID-19 times. The findings show that psychological distress due to this pandemic affects not only negatively but also positively the spouse interpersonal relationships. The study addresses this distress between spouses and suggests some psycho-social and environmental coping strategies for psychologists and therapists such as conflict resolution, self-introspection, inter-communication improvement, developed a sense of obligation, recognizing stressors and preparing a plan of action and seeking professional help to improve the negative outcomes of spouse interpersonal relationship in this pandemic.

\section{REFERENCES}

1. Xiang YT, Yang Y, Li W, Zhang L, Zhang Q, Cheung T, Ng CH. Timely mental health care for the 2019 novel coronavirus outbreak is urgently needed. The Lancet Psychiatry 2020;7(3):228-9.

2. Lau JTF, Tsui HY, Kim JH, Chan PKS, Griffiths S. Monitoring of perceptions, anticipated behavioral, and psychological responses related to H5N1 influenza. Infection 2010;38(4):275-83.

3. Hollifield M, Hewage C, Gunawardena CN, Kodituwakku P, Bopagoda K, Weerarathnege K, International Post-Tsunami Study Group. Symptoms and coping in Sri Lanka 20-21 months after the 2004 tsunami. The $\mathrm{Br}$ J Psychiatry 2008;192(1):39-44.

4. Taylor MR, Agho KE, Stevens GJ, Raphael B. Factors influencing psychological distress during a disease epidemic: data from Australia's first outbreak of equine influenza. BMC Pub Health 2008;8(1):347.

5. Brooks SK, Webster RK, Smith LE, Woodland L, Wessely S, Greenberg N, Rubin GJ. The psychological impact of quarantine and how to reduce it: rapid review of the evidence. The Lancet 2020;10227(395):912-20.

6. Germani A, Buratta L, Delvecchio E, Mazzeschi C. Emerging Adults and COVID-19: The Role of Individualism-Collectivism on Perceived Risks and Psychological Maladjustment. Int J Environ Res Pub Health 2020;17(10):3497.

7. Sáez G, Ruiz MJ, Delclós-López G, Expósito F, Fernández-Artamendi S. The effect of prescription drugs and alcohol consumption on intimate partner violence victim blaming. Int $\mathrm{J}$ Environ Res Pub Health 2020;17(13):4747. 
8. Scheffer Lindgren M, Renck B. 'It is still so deep-seated, the fear': psychological stress reactions as consequences of intimate partner violence. J Psychiatr Ment Health Nurs 2008;15(3):219-28.

9. Kaukinen C. When Stay-at-Home Orders Leave Victims Unsafe at Home: Exploring the Risk and Consequences of Intimate Partner Violence during the COVID-19 Pandemic. Am J Crim Justice 2020;1:1-12.

10. Cohan CL. Family transitions following natural and terrorist disaster: Hurricane Hugo and the September 11 terrorist attack. In Handbook of stressful transitions across the lifespan (pp. 149-164). Springer, New York, NY; 2010.

11. Browne DT, Plamondon A, Prime H, Puente-Duran S, Wade M. Cumulative risk and developmental health: an argument for the importance of a family-wide science. Wiley Interdisciplinary Reviews: Cogn Sci 2015;6(4): 397-407.

12. Pietromonaco PR, Overall NC. Applying relationship science to evaluate how the COVID-19 pandemic may impact couples' relationships. Amer Psychol 2021;76(3):438-50.

13. Karney BR, Story LB, Bradbury TN. Marriages in Context: Interactions Between Chronic and Acute Stress Among Newlyweds. In T. A. Revenson, K. Kayser, \& G. Bodenmann (Eds.), Decade of behavior. Couples coping with stress: Emerging perspectives on dyadic coping (p. 13-32). American Psychological Association; 2005.

14. Barton AW, Beach SR, Bryant CM, Lavner JA, Brody GH. Stress spillover, African Americans' couple and health outcomes, and the stress-buffering effect of family-centered prevention. J Fam Psychol 2018;32(2):18695.

15. Barton AW, Bryant CM. Financial strain, trajectories of marital processes, and African American newlyweds' marital instability. J Fam Psychol 2016;30(6):657-67.

16. Kessler RC, Andrews G, Colpe LJ, Hiripi E, Normand SL, Walters EE, Zaslavsky AM. Short screening scales to monitor population prevalences and trends in non-specific psychological distress. Psychol Med 2002;32(6):959-76.

17. Pandey MK. Individual Project on Psycho-Social Impact of COVID-19 Pandemic on our Life., Department of Applied Psychologist, Veer Bahadur Singh Purvanchal University, Jaunpur, Uttar Pradesh, India; 2020.

18. Mesa Vieira C, Franco OH, Gómez Restrepo C, Abel T. COVID-19: The forgotten priorities of the pandemic. Maturitas 2020;136:38-41.

19. Simonovic D. States Must Combat Domestic Violence in the Context of COVID-19 Lockdowns-UN Rights Expert. United Nations Office of the High Commissioner for Human Rights, Geneva; 2020.

20. Times G. Chinese city experiencing a divorce peak as a repercussion of COVID-19. Global Times; 2020.

21. Rauf M, Raza A. Psychological distress and interpersonal relationships among special education teachers. Rawal Med J 2019;44(2):294-7.

22. Kenny R, Dooley B, Fitzgerald A. Interpersonal relationships and emotional distress in adolescence. J Adolescence 2013;36(2):351-60.

23. Luetke M, Hensel D, Herbenick D, Rosenberg M. Romantic Relationship Conflict Due to the COVID-19 Pandemic and Changes in Intimate and Sexual Behaviors in a Nationally Representative Sample of American Adults. J Sex Marit Ther 2020;1:1-16.

24. Costoya V, Echeverria L, Edo M, Rocha A, Thailinger A. The impact of COVID-19 in the allocation of time within couples. Evidence for Argentina., Unpublished Manuscript, Universidad de San Andrés; 2020.

25. Günther-Bel C, Vilaregut A, Carratala E, Torras-Garat S, Pérez-Testor C. A Mixed-method Study of Individual, Couple, and Parental Functioning During the State-regulated COVID-19 Lockdown in Spain. Fam Process 2020;59(3):1060-79.

26. Morales-Vives F, Dueñas JM, Vigil-Colet A, Camarero-Figuerola M. Psychological Variables Related to Adaptation to the COVID-19 Lockdown in Spain. Front Psychol 2020;11:2438.

$* * * * * * * * * * * * * * * * * * * * * * * * * * * * * * * * * * * *$

Acknowledgements - Nil

Conflict of Interest - Nil

Funding - Nil 